\title{
Fair Value Accounting: Current Status And A Proposal For Convergence
}

\author{
Catherine Baluch, Gartner, Inc., USA \\ Reuben Cohen, Internal Revenue Service, USA \\ Henry Soto, Internal Medicine Associates, USA \\ Pamela Tucker, FGCU, USA \\ Ara Volkan, FGCU, USA \\ Gail Wright, FGCU, USA
}

\begin{abstract}
Accounting for fair values is a complex subject full of controversial recognition, measurement, and reporting rules. This paper first analyzes the current status of fair value accounting, highlighting the criticisms of the current fair value accounting standards. Next, the U.S. and international standards are discussed to highlight the areas where they differ. Finally, an accounting approach for fair values is proposed that reports the economic reality and the financial condition of a firm and may be used to achieve global convergence.
\end{abstract}

Keywords: fair value accounting; global convergence; other than temporary impairments

\section{INTRODUCTION}

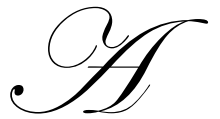

ccounting for fair values is a complex subject full of controversial recognition, measurement, and reporting rules. Previously, all assets were reported at their historical cost, a valuation that was verifiable and based on reliable evidence. The Financial Accounting Standards Board (FASB) began migrating towards fair value in 1993. At that time, the standards required that all debt and equity investments classified as trading securities or available-for-sale securities be reported in the financial statements at their fair values. Due to the complexity of fair value accounting rules, additional pronouncements have been implemented to provide guidance on recognition, measurement, and reporting of financial instruments, hedges, and other assets and liabilities at fair value (FASB, ASC 820 and 825). The FASB issued these standards in order to ensure consistency and comparability in fair value measurements and for expanded disclosures about fair value measurements.

\section{BACKGROUND}

ASC 820 was effective for financial statements issued for fiscal years beginning after November 15, 2007, and interim periods within those fiscal years. This statement did not require additional use of the fair value method; rather, this statement provided clarification as to how assets and liabilities requiring fair value treatment should be marked-to-market. It defined fair value as the exit price or the price that would be received to sell an asset or paid to transfer a liability in an orderly transaction between market participants. This guidance established three levels by which assets and liabilities could be classified to show financial statement readers the amount of certainty that pertains to the valuation of the various securities (Boyles, 2008).

Level 1 classification reflects those assets and liabilities whose fair value can be assessed with the highest degree of certainty. Certainty in this case means having an active market in which these instruments are traded with objective evidence supporting the market value of Level 1 items. A Level 1 classification provides financial statements users with a high degree of confidence that the amounts reflected on the balance sheet for these items represent of their true fair value. 
Assets and liabilities classified as Level 2 are reported at fair value but with more uncertainty surrounding their true value due to the absence of an observable, active market for these instruments. Therefore, FASB determined that the fair value measurement for these items would require inputs that are observable for similar assets or liabilities, either directly or indirectly, through corroboration with observable market data. The FASB also confirmed that observation of the substituted inputs used for fair value measurement must be observable for the full term of the item, where an item was subject to a precise term, such as with a contracted interest rate swap (Fuglister and Bloom, 2008).

The Level 3 classification provides financial statements users with the greatest uncertainty regarding the item's true fair value. Due to the lack of measurable market data to assess the fair value of these items, companies must identify other inputs that can be used to determine the fair value measurement. According to ASC 820, the required inputs for this classification should be those that reflect the reporting entity's perceptions about the assumptions market participants would use in pricing the asset or liability (including assumptions about risks) based on the best information available in the circumstances. Bates et al (2009) summarize these classifications, reproduced here as Table 1.

Table 1: ASC 820 Descriptions of the Faire value Hierarchy

\begin{tabular}{|c|c|c|c|c|}
\hline Classification & Market Condition & Example & FAS 157 Treatment & Valuation Certainty \\
\hline Level 1 & $\begin{array}{l}\text { Readily observable } \\
\text { market price }\end{array}$ & $\begin{array}{l}\text { Stocks or bonds traded } \\
\text { on the New York Stock } \\
\text { Exchange }\end{array}$ & $\begin{array}{l}\text { - Mark-to-market } \\
\text { - Market value determined by } \\
\text { observable prices at which } \\
\text { willing buyers and sellers are } \\
\text { exchanging the instrument }\end{array}$ & $\begin{array}{l}\text { High degree of } \\
\text { certainty }\end{array}$ \\
\hline Level 2 & $\begin{array}{l}\text { No readily } \\
\text { observable market } \\
\text { price, but does have } \\
\text { observable inputs } \\
\text { based on market } \\
\text { prices }\end{array}$ & $\begin{array}{l}\text { Derivative instrument } \\
\text { whose value is based } \\
\text { upon movements in the } \\
10 \text {-year Treasury bond }\end{array}$ & $\begin{array}{l}\text { - Mark-to-model } \\
\text { - Market value determined by } \\
\text { pricing model }\end{array}$ & $\begin{array}{l}\text { Lower degree of } \\
\text { certainty }\end{array}$ \\
\hline Level 3 & $\begin{array}{l}\text { No readily } \\
\text { observable market } \\
\text { price, and no } \\
\text { observable market } \\
\text { price for one or } \\
\text { more inputs }\end{array}$ & $\begin{array}{l}\text { Investment in a non- } \\
\text { publicly traded } \\
\text { company that does not } \\
\text { publicly disclose } \\
\text { financial statements }\end{array}$ & $\begin{array}{l}\text { - Mark-to-estimate } \\
\text { - Market value determined by } \\
\text { estimate by those involved in } \\
\text { preparing the financial } \\
\text { statement }\end{array}$ & $\begin{array}{l}\text { Very low degree of } \\
\text { certainty }\end{array}$ \\
\hline
\end{tabular}

\section{PURPOSE}

This paper first analyzes the current status of fair value accounting, highlighting the criticisms of the fair value accounting standards. Next, the U.S. and international standards are discussed to highlight the areas where they differ. Finally, an accounting approach for fair values is proposed that reports the economic reality and the financial condition of a firm and may be used to achieve global convergence.

\section{CONCERNS AND CRITICISM OF USERS AND REPORTING ENTITIES}

Concerns about ASC 820 and 825 fall into two inter-related categories: timing required for implementation of the new fair value standards and the requirement to use exit value for Level 3, illiquid assets and liabilities. Under fair value accounting, banks and many corporations were required to re-classify assets and liabilities that had formerly enjoyed active markets and Level 1 valuation processes into Level 3 category because the market for these items had become toxic and illiquid.

During the 2008-2009 market decline, problems with illiquid markets became apparent when the housing market fell and assets backed by sub-prime mortgages declined in value as well. Financial institutions holding these assets were required to value the assets using Level 3 inputs (Ryan, 2009). Because of the use of Level 3 inputs, 
some critics blame the recent financial failures on fair valuations. They believe that an illiquid market has resulted in the valuation of assets well below their true economic value (Ma and MacNamara, 2009). However, others believe that fair value accounting provides useful information to investors (Zabel, 2009).

Fair values can be estimated using three different valuation techniques; the Market Approach, Income Approach and Cost Approach. Valuation techniques may be used separately or jointly and are used in conjunction with input levels. If the reporting entity is using Level 1 inputs, then the use of a single valuation technique is probably sufficient. If multiple valuation techniques are used, the results must be evaluated and weighted appropriately. A fair value measurement is the point within the reasonable range of the results that is most representative of fair value in the circumstances. Valuation techniques should be consistently applied, but can be changed if the change results in a measurement that is equally or more representative of fair value in the circumstances. A change in the valuation technique is a change in accounting estimate, not a change in accounting principle (Krumwiede, Scadding, and Stevens, 2008).

Katz (2008) describes the negative side associated with fair-value measurements. As the risk that companies won't pay back their debts rises, their reported liabilities actually decrease. That's because companies estimating the fair value of their own liabilities must factor in the risk that they won't pay those debts off. That makes the market value of the anticipated debt smaller. On the other hand, if the debtor becomes more creditworthy, the fair value of the debt obligation rises.

Companies, such as banks, feared fair value because their holdings of Level 3 assets were substantial. Since Level 3 inputs have a very low degree of certainty, they require management's own assumptions on how the market participant would value the asset or liability. On the other hand, users of financial statements felt that they were not being properly informed about the economic impact on the reporting entity of gains and losses associated with changes in the fair values of assets and liabilities owed or owned. They asserted that, had they been provided this information, they might well have made different decisions regarding investing in, lending to, or entering into business transactions with the reporting entities (Epstein, Nach, and Bragg, 2008).

\section{Companies Blame Fair Value Accounting for the Current Economic Crisis}

While users appreciate the information provided by fair value accounting, several studies blame the current economic crisis on the same standards. Lost in this controversy is the fact that the responsibility for failure falls on the management of companies that invested in high risk/high reward financial instruments. In addition, real estate agents, loan originators, appraisers, and lawyers all share in the blame. These teams of professionals aided many to enter into contracts that they were in no position to enter into and had no means to fulfill.

Many people chose to place blame on the accounting rules for the economic meltdown that occurred. Figure 1 tracks the relationship between quarterly operating EPS for the S\&P 500 (solid line) and the net EPS, which includes write downs and other special one-time items (Holmes, 2009). For most of the past 20 years, the two lines have moved together, but a look at the far right side reveals that 2008-09 was another matter. While the operating profits were down, net earnings declined three times faster. A strong case could be made that the sharp drop-off in net earnings was largely due to fair value-related write downs by financial companies, which were the largest sector of the S\&P 500. The health of the financial sector is very important, but fair value accounting takes away the time these institutions need to heal. A lack of healing time in the 1930s deepened and prolonged the Great Depression. 


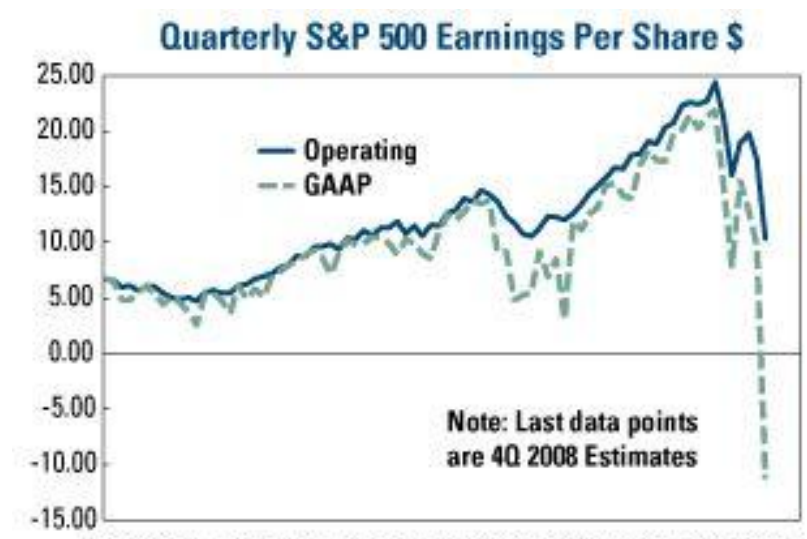

19891991199319951997199920012003200520072009

Source: S\&P, Thomson Financial, Citi

Figure 1

Financial institutions have many complaints concerning the new standards. They blame fair value accounting rules for their losses and lost opportunities. Many banks decided to forego investments in other financial institutions because the valuations using the fair value standards would not support the acquisitions they planned. In addition, certain loans that were originally considered held-to maturity and valued at amortized cost may now be fair-valued quarterly, incurring unrealized losses (Dzinkowski 2009). Thus, there may be a use for both the historical cost as well as the fair-value approach. The main issue is how to combine the benefits of both approaches while simultaneously maintaining transparency and representational faithfulness.

\section{Criticisms of ASC 820 and 825}

While FASB's intention in ASC 820 was to provide a clear and concise framework for fair value measurement, the statement was met with harsh reactions due to the timing of when this statement went into effect. For a number of companies, the fiscal year 2008 financial statements were the first statements to recognize these new fair value guidelines. At the same time, the country headed into a financial crisis. This ignited a debate as to whether the fair value standards played a role in the financial crisis. As the housing market experienced significant decline, many financial institutions with mortgage-backed securities had to reflect a write-down of these securities to fair value under the new guidance. This resulted in financial institutions reporting massive losses in their financial statements. Forbes magazine (March 23, 2009) estimated that financial institutions have written off more than $\$ 700$ billion using these rules.

One of the major criticisms of the statement was how illiquid items should be valued under fair value guidelines. Users found that guidance provided for measuring fair value of illiquid items was ambiguous as they did not believe there was an appropriate way to determine the proper fair value of these items. The standards do not include a requirement to verify whether the assumptions are in line with those of market participants (Trussel and Rose, 2009). Miller (2008) discusses this criticism and agrees that the added uncertainty in determining the exit value of illiquid items may not translate into any additional benefits for financial statement users. He believes that the use of exit value is a prescription for increased earnings volatility, more widespread earnings management, and self-determined bonuses on a grand scale.

Preparers have raised concerns as to how their auditors have interpreted the guidance when conducting an audit of the company's financial statements (Norris, 2009). Critics alleged that auditors were requiring fair value determination based on quoted prices, even where active or orderly markets were absent (Campbell, Owens-Jackson, and Robinson, 2008; King, 2009). This issue only exacerbated the frustration of users as they attempted to understand the three-level classification structure presented in the standards. 
Discontent over fair value accounting rules (ASC 820) extended to politicians and lobbyists as the country's financial condition continued to deteriorate. This group's criticism went beyond questioning valuation techniques, targeting the use of fair value accounting itself. Politicians and lobbyists questioned whether to revert back to historical cost principle or if a hybrid method should be used when preparing financial statements. While Levitt and Breeden (2009) eloquently defended fair value accounting in Congressional testimony, lawmakers went in the opposite direction.

Congress believed that additional research was needed before a determination could be made. In the interim, Congress passed a bill to impede the application of fair value accounting. This bill, the Emergency Economic Stabilization Act of 2008 (EESA), became law in October 2008. Sections 132 and 133 of this law contained significant implications for FASB as it attempted to appease investors during the troubled financial times. EESA states that the Securities and Exchange Commission (SEC) shall have the authority under the securities laws to suspend, by rule, regulation, or order, the application of fair value accounting standards for any issuer or with respect to any class or category of transaction if the SEC determines that it is necessary or appropriate to do so in the public interest and to protect investors (Trussel and Rose, 2009).

The details of research to be conducted on fair value accounting were discussed in Section 133 of the EESA and enhanced the scope of the SEC's review of fair value accounting rules, requiring the SEC to review the process by which FASB generates new accounting standards. While the SEC has the authority to set the accounting standards for public companies, it usually relies on the FASB to develop accounting standards. However, this request by Congress questioned FASB's authority as the standard setter for the accounting profession.

\section{REVISIONS TO ASC 820 and 825}

The passage of the EESA into law shifted the demand for action from Congress to the SEC and the FASB. FASB issued three staff position papers in the wake of concerns and criticism expressed about SFAS 157. The first one, "Determining Fair Value When the Volume and Level of Activity for the Asset or Liability Have Significantly Decreased and Identifying Transactions That Are Not Orderly," clarified the application of the fair value hierarchy in an inactive market and provided an example to illustrate key considerations in determining the fair value of a financial asset when the market for that financial asset had become inactive. These revisions to ASC 820 and 825 provided more detailed analysis tools for determining when a market is no longer active and when a transaction is not orderly (Trott, 2009).

This staff position paper addressed the criticism that the accounting profession has not done an adequate job of explaining that mark-to-market does not apply when there is no market. The uncertainty of how fair value treatment applies to these items is related primarily to items that would fall under the Level 2 or 3 classifications. In inactive and disorderly markets, the quoted price of an asset or liability often is not its fair value. More analysis and the use of other valuation techniques may be required to approximate its fair value. As enunciated in the standards, potential valuation alternatives include discounted cash flows model, economic value added model, and the multiples of various earnings models.

FASB's response confirmed that a thorough analysis of current economic conditions must also factor into the calculation of fair value, as these conditions may have an erroneous affect on the current market price. Market characteristics that users should be aware of when applying a fair value measurement to assets and liabilities include a paucity of recent transactions, volatile prices, and widened bid-ask spreads, among others (Epstein, 2009). In the presence of such characteristics, users must then employ other valuation alternatives when assessing the fair value of these assets and liabilities.

"Recognition and Presentation of Other-Than-Temporary Impairments" sought to address concerns regarding reporting that is required for impairments to the value of held-to-maturity and available-for-sale securities. These revisions promulgated procedures that will be used to report the loss realized for a decline in the value of a debt financial instrument. The only way to avoid reporting the loss in the income statement is to demonstrate that management had both the intent and the ability to hold the investments for a sufficient time for a price recovery to occur (Foster and Shastri, 2010). This staff position did not apply to equity securities but modified the original 
criteria required to avoid loss recognition for debt securities classified as held-to-maturity and available-for-sale securities by changing the required management viewpoint. Whereas formerly a positive assertion of intent to hold was required, now only an assertion of a present lack of intent to sell, coupled with a modest expectation (more likely than not equals a greater than 50\% probability not the bar set in contingency standards that require a $90 \%$ probability) of not being forced to sell, will be required to avoid recognizing a loss in the current period (McDonald, 2010).

The staff position paper allowed more companies to avoid loss recognition on the income statement by broadening the conditions previously required under the old standards. If the entity does not plan to sell a security and it is determined that it is not more likely than not that it will be required to sell the security before recovery of its cost basis, then the impairment is separated into two amounts: (1) the amount of the total other-than-temporary impairment (OTTI) related to credit issues in the debt security which is recognized in earnings; and (2) the amount of the total OTTI related to all other factors which is recognized in other comprehensive income. Thus, the current US standards have two impairment models for financial instruments, one for equity securities and another for debt securities.

"Interim Disclosures About Fair Value of Financial Instruments," the third staff position paper issued on April 9, 2009, revised the interim disclosures about fair value of financial instruments. While the other staff positions focused on addressing criticisms of financial statement preparers in terms of how fair value measurements should be applied, this staff position focuses on meeting the needs of financial statement users. Applying only to publicly held companies, the staff position paper extended disclosure requirements to summary interim financial information, mandating tabular or other presentations to compare carrying amounts to fair value amounts, and disclosure of the methods and significant assumptions employed to develop fair value estimates (Epstein, 2009).

The SEC completed their review of fair value accounting during the three month period following the passage of the EESA. The Report and Recommendations Pursuant to Section 133 of the Emergency Economic Stabilization Act of 2008: Study on Mark-to-Market Accounting was issued by the SEC on December 30, 2008 as its response to concerns and criticisms of fair value accounting. The report determined that fair value accounting was not to blame for the financial crisis. In reviewing fair value accounting, the SEC highlighted areas where they believed the standards should be amended but did not choose to exercise their authority to halt the use of fair value accounting. Their recommendations included issuing additional guidance on determining fair asset and liability values in illiquid markets and detailed disclosures on how those values are calculated (Cheng, 2009).

Although the SEC concluded that while fair value accounting did not spur the financial crisis, the interpretation of fair value being equal to the exit price may have contributed to the situation. While FASB has taken steps to explain, modify and narrow the application of fair values, it has not retreated from the underlying principles and approaches to fair value accounting.

\section{GUIDANCE ON APPLYING FAIR VALUE TO ASSETS AND LIABILITIES}

Fair value is the price that would be received to sell an asset or paid to transfer a liability in an orderly transaction between market participants at the measurement date. An orderly transaction is measured on the balance sheet date at market value as if the asset or liability were to be disposed (the exit price). Exit price is the hypothetical price an entity would receive for selling its asset or the price a market participant would pay to incur or transfer the liability.

The asset or liability to be sold or transferred is to be measured at fair value in the principal market for that asset or liability. FASB defines the principal market as the market in which the reporting entity would sell the asset or transfer the liability with the greatest volume and level of activity for the asset or liability. If a principal market does not exist then the most advantageous market for the asset or liability is to be used. The most advantageous market is defined as the market in which the reporting entity would sell the asset or transfer the liability with the price that maximizes the amount that would be received for the asset or minimizes the amount that would be paid to transfer the liability considering costs in the respective market. When valuing an asset in its principal market, the reporting entity must use the value given, even if another market may give a more advantageous value; however, if 
the asset does not have a principal market, then the market with the highest value (most advantageous) should be used.

\section{Disclosure Requirements}

For all assets and liabilities measured at fair value on a recurring basis, the FASB requires reporting entities to disclose the following information at each interim or annual period for each major category of assets and liabilities:

a. The fair value measurements at the reporting date.

b. The level in the fair value hierarchy that the assets or liabilities are measured.

c. A reconciliation of the beginning and ending balances, with separate notation for changes during the period for all Level 3, unobservable inputs, to include: realized and unrealized gains and losses; purchases, sales, issuances, and net settlements.

d. Amount of total gains and losses in (c) due to the change in unrealized gains and losses.

e. Annually, the valuation technique used and any changes in valuation techniques.

Assets and liabilities measured at fair value on a nonrecurring basis (impairments) in periods subsequent to initial recognition shall have the following disclosures:

a. $\quad$ Fair value measurements used during the period and reasons for the measurements.

b. The level in the fair value hierarchy that the assets or liabilities are measured.

c. If using significant unobservable inputs, a description of the inputs and information used to develop the inputs is required.

d. Annually, the valuation technique used and any changes in valuation techniques used to measure similar assets and liabilities in prior periods.

\section{INVESTOR RESPONSE TO FAIR VALUE REPORTING}

The average investor in publicly held companies did not have the necessary knowledge to understand all of the information contained in the financial statements or the notes to the statements. Their overall knowledge did not include an understanding of how management arrives at fair value estimates for assets or liabilities. Not only did fair value accounting affect the average investor, but it also affected investment firms in their analysis of a company's going concern status. Confidence levels were eroded to such a degree that it affected a broad array of core activities, including contingent liabilities, mergers and acquisitions, intangible assets, pensions, hedges, environmental-cleanup obligations, and loans (Katz, 2008). Most users state that FASB's intentions of a more clear and precise valuation of assets and liabilities have not been achieved with ASC 820 and 825.

Confidence levels in the financial reports of companies prior to the issuance of ASC 820 changes to valuation of assets and liabilities were higher when the market was at normal levels. However, when companies started to put money in subpar investments then incurred massive losses, investors started to pay attention to financial statements issued under new guidelines. Investors discovered that transparency and clarity of information that was assumed to exist did not in fact match expectations. Investment companies had to make changes to meet the new requirements and to remain viable in a down market.

J. P. Morgan's investment arm is an example of changes brought on by the simultaneous occurrence of the financial crisis and implementation of fair value accounting. The processes J.P. Morgan implemented during the crisis recovery phase illustrate the reaction of many investment companies. These processes addressed many compliance challenges, including monitoring and documentation, fully understanding the challenges and opportunities, having the ability to craft all disclosure in plain English, and having the resources to review disclosures for inaccuracies and omissions (Donatio, 2009). Five base practices form the starting point to maximize the quality of the valuation process, including: 
Process - Well-documented procedures, including a hierarchy of pricing sources and flexibility in the process for judgment.

People - A balanced mix, including finance and accounting, investment, and legal and compliance professionals.

Lessons learned program - Post-meeting reflection that captures valuable insights on how the procedures are operating and key changes or updates needed.

Documentation - Board reporting that explains any inconsistent evidence and reasons behind pricing challenges.

Diligence - A testing plan for monitoring quoted versus actual prices, and due diligence from the board to ensure valuation questions are answered satisfactorily.

Holmes (2009) stated that lacking capital, the banks would cut back on loans, which will hurt manufacturers and others that need access to short-term working capital to run their businesses. Products will not get made, workers will not be paid and before long the economy will grind to a halt. While these predictions became reality, Mosso (2010) stated that the role of fair value accounting has been settled. As a former member of FASB, Mosso supports the FASB requirement to report assets and liabilities at fair value. Currently however, investor attitudes have cycled back to concerns that the values are being overstated due to the revisions to ASC 820 and 825 that allow more lenient accounting for OTTI. The overall view from investors is that the proposed changes will allow firms to make their financial condition appear rosier than reality. In addition, some view the FASB staff positions as crippling the concept of fair-value accounting and believe they will result in untimely data for investors, lack of transparency, reduced comparability, inconsistency, and possible manipulation as management will be allowed to exercise more judgment. Finally, the perceived influence of the financial industry and Congress on the FASB's standard setting due process caused some accounting stakeholders to worry about the board's independence. The revisions to ASC 820 and 825 favor the providers of financial information. Cheng (2009) believes it was done in a rush to boost the pending first quarter numbers for companies struggling through the current financial crisis.

\section{FASB's INFLUENCE ON GLOBAL STANDARDS AND THE IASB}

The United States has a great influence on standards set forth by the International Accounting Standards Board (IASB). This influence comes in the form of peer pressure exerted on the IASB to match certain changes that the FASB has made specifically to fair valuation of assets. European Union officials were pressuring the IASB to match the speed at which the FASB had made changes to their reporting standards. However, in a turn of events, the IASB decided that a hasty global convergence in fair value accounting was neither necessary nor productive. Both organizations agree that alignment at this point in time would not be in the best interests of all parties, and that the focus now should be on simplification of the standards currently in place by the IASB.

Recent changes by the FASB have been an attempt to require companies to be transparent in their reporting of assets and liabilities. The fair-value methods practiced by European countries have been in use for quite some time. Thus, the U.S. standards must be aligned with global standards. Current global standards do not allow for other-than-temporary impairments (OTTI). Such impairments can only be recognized if there is an expectation of default on contractual cash flows (Arya and Reinstein, 2010). The benefits of convergence would carry over international borders to the advantage of investors by helping them in researching investment opportunities and making decisions. Hopefully, the even playing field created would lead to consistency and comparability in accounting and reporting for financial assets and liabilities.

\section{IASB's Influence on Consumer Confidence}

European investors and those in political positions expressed a deep concern regarding the suggested changes to IASB's standards associated with the fair-value approach, asset impairment, and liability mark-to-market valuations. In order to provide transparency and reflect economic reality, the IASB's emphasis has been to define, in a balanced and transparent way, the appropriate criteria for classifying instruments to be measured at cost and at fair value and not to increase or decrease arbitrarily the use of fair value. Whether there is a decrease or an increase of 
fair value will depend on a particular institution's business model and holdings (Duangploy and Pence, 2010).

The IASB is currently working with the FASB to change their standards to implement the simplification project that is ongoing in the area of fair value accounting. Both the preparers of the financial statements and the investors who use the information have a stake in this project. The objective of this project is to build user confidence so all parties will support the standards and the investment climate will improve. The IASB is trying to collapse four models of financial investment classifications into two: financial instruments measured at fair value and at amortized cost. Another objective of the IASB is to eliminate the need to use OTTI procedures. The IASB believes that the use of the OTTI approach has diminished the transparency of the fair value information.

Many investors and preparers place the blame of the financial crisis on the current accounting standards. However, any changes made to these standards should be done using a thorough review process and input from all stakeholders. A single set of standards would improve transparency and investor confidence, and prevent firms being placed at a competitive disadvantage to rivals that use less exacting standards.

\section{RECOMMENDATIONS}

\section{The Hybrid Approach: a Model for Convergence}

It is clear from the discussion above that all stakeholders understand the limitations of the fair value approach in situations where the historical cost approach would give a truer sense of the economic reality of a company. This would be particularly appropriate when reporting for Level 3 assets and liabilities since in these situations fair value accounting is inefficient. Fair value does not report assets at their future earnings potential (Allen and Carletti, 2008). In contrast to historical cost accounting, fair value accounting adds artificial risk that diminishes the information value of asset prices and leads to suboptimal decisions. The damage done by marking to market is greatest when claims are long lived, illiquid, and senior (Plantin, Sapra, and Shin, 2008). Therefore, the FASB should consider an accounting approach that incorporates both an historical cost approach and a fair value approach. This hybrid approach would be comparable to the global accounting standards that account for financial instruments in four categories, one of which uses the historical cost model as the basis of measurement and reporting (Table 2).

Table 2: A Hybrid Approach to Valuation

\begin{tabular}{|l|l|l|l|l|}
\hline \multicolumn{1}{|c|}{ Asset Category } & \multicolumn{1}{|c|}{ Valuation } & $\begin{array}{l}\text { Unrealized Gain or } \\
\text { Loss Reported in }\end{array}$ & \multicolumn{1}{c|}{ Disclosure } & $\begin{array}{c}\text { Similar to FASB Position } \\
\text { on }\end{array}$ \\
\hline Liquid, short-term & Fair value & Earnings & Historical cost & $\begin{array}{l}\text { Level } 1 \text { and Level } 2 \\
\text { Evidence }\end{array}$ \\
\hline Illiquid, long- term & $\begin{array}{l}\text { Amortized historical } \\
\text { cost }\end{array}$ & $\begin{array}{l}\text { Not Applicable } \\
\text { Standards for probable } \\
\text { impairments apply }\end{array}$ & $\begin{array}{l}\text { Pro forma impact of } \\
\text { fair value on earnings } \\
\text { measurable } \\
\text { impairments reported } \\
\text { in earnings }\end{array}$ & $\begin{array}{l}\text { Impairment } 3 \text { evidence } \\
\text { information }\end{array}$ \\
\hline
\end{tabular}

Under the hybrid approach, either fair value or historical cost accounting would be utilized based on which approach would be the most efficient in determining the valuation of financial assets and liabilities. There are two categories under the hybrid approach. The first category consists of liquid financial assets with a short term holding periods that are measured at fair value with the unrealized gain or loss reported as part of income. This would be similar to the accounting for Level 1 and 2 assets and would also be consistent with one of the two categories proposed by the IASB.

The second category has illiquid financial assets and liabilities with long-term holding periods which are valued at (amortized) historical costs with no adjustments to income or comprehensive income. This category would 
be similar to held-to-maturity portfolio in accounting for debt securities and Level 3 assets under current standards. Unlike Level 3, however, the assets would be valued at historical cost rather than fair value. The use of historical cost for this category is consistent with studies suggesting historical cost accounting is more efficient for illiquid, long-term financial assets. Since the IASB standards do not contain OTTI procedures, eliminating this would be an area for convergence. Finally, standards governing the valuation of assets that test balance sheet items for impairment will apply to investment assets, with impairments recognized if they are probable (e.g., the 90 percent probability level that is commonly used in decisions to recognize contingencies) and measureable.

It would be beneficial to align the US fair value standards with the global standards. Convergence leads to rapid response times when revisions are needed to fair value standards to better report economic reality. Presently, in the crucial area of fair value accounting, the US and global standards are not moving in tandem. The IASB is preparing final rules that will clarify when banks can ignore fair value. If the divergent rules continue to exist, there is a risk of a race to the bottom, with investors being the losers. Because the IASB is working to reduce their four current classifications into two categories, the proposed hybrid approach may be a model to bring about convergence.

\section{Safe Harbor}

Because of controversies surrounding fair value accounting, creation of a safe harbor for officers, preparers and auditors when they are using reasonable business judgment may be appropriate. A safe harbor is a regulation that reduces or eliminates a party's liability under the law on the condition that the party performed its actions in good faith. This would allow room for common sense where rules may be too strict. The fear of personal culpability may help influence corporate officers and auditors to act more conservatively than they should. Dzinkowski (2009) describes situations where, faced with unusual circumstances, preparers and auditors were unwilling to exercise much judgment. When faced with the possibility of a 20 -year jail sentence under Sarbanes-Oxley, preparers and their auditors acted conservatively. If auditors are shielded from such liability, then they would be able to more accurately measure the value of investments as intended by the FASB.

\section{Ban Exit Pricing When There Is No Intention to Exit}

Under certain circumstances, securities are valued at the most recent selling price even when a company has no need or intention to sell at those prices. Financial statement security values would be based on liquidation values rather than valid fair values linked to management's plan for these assets. Using exit prices for securities without considering all the facts and circumstances results in very low valuations when the markets are distressed. Questionable paper losses would result based on broker quotes while in future periods, artificial gains may be created and recorded in operating income.

If sudden and large paper losses result from unusual market activity or temporary market decline in security prices, these prices may cause investors and shareholders to lose confidence in a company or its financial statements. This would not occur if the securities held until recovery or beyond are valued at (amortized) historical cost. A company could face the prospect that it may need to raise capital on short notice due to large paper losses from a rapid downward spiral of securities even though a company would still have the ability to hold them until recovery. If a company's liquidity needs do not require it to sell temporarily depressed securities, its capital position should not be penalized as if it would.

If an enterprise uses fair value to measure a significant portion of its assets, the results for the entire quarter can hinge upon the last trades made during the last hour on the last day of the quarter. If there is any significant economic or business news that day, it could make or break the reported results for the quarter. Gross (2009) suggests that this provides for an extremely unbalanced scorecard for management's performance for the period. The requirement to use exit prices should therefore be revised. When near-term exit is not intended or if a sale does not reflect the strategy of a company, then exit pricing should not be the required basis for measuring assets. Also, because broker quotes may point to the market's demand for smaller quantities of a security or class of securities, then broker quotes should not be used to determine fair value if there is no intention to sell. 
The FASB should expand the factors that indicate an inactive market. Currently, these variables are limited to the number of buyers and the customary time the item on sale is exposed to the market. Gross (2009) recommends that factors should include a significant widening of bid-ask spreads, significant reduction from the normal number of transactions in a market, trades occurring primarily by sellers who are financially troubled, buyers that are not the normal market players but rather are opportunistic players looking for a bargain, and non-distressed sellers sitting on the sidelines and unwilling to sell in the current market at the prices being offered.

\section{Loosen the Tainting Rules}

With a few exceptions, strict tainting rules prohibit all sales of securities held to maturity and all sales of available for sale securities which have a loss. These rules prevent management from managing their portfolios due to the fear of tainting the portfolio. While held-to-maturity securities should be subject to strict tainting rules, some trading (e.g., five percent of the portfolio value) should be allowed without calling into question management's intent and ability to hold the remainder of portfolio to recovery. Such a change would be consistent with similar changes proposed under new IASB rules.

\section{CONCLUSION}

Fair value accounting was implemented in the middle of a financial crisis causing many to blame the FASB for the decline in the financial system. ASC 820 and 825 required issuers of financial statements to value their assets and liabilities at realistic values. However, in the long term, fluctuations in the market and adjustments for credit risk may cause assets and liabilities to be valued inconsistently. To address these flaws in the current standards, a hybrid method that uses both fair value and historical cost could be used. Also, more authority should be given to senior management and auditors to make reasonable judgments, while concurrently indemnifying them against certain professional liabilities.

\section{RECOMMENDATIONS FOR FUTURE RESEARCH}

Future research may track the impact of having divergent accounting rules in the US and the global arena on capital markets. In addition, the researcher should identify if and when convergence in fair value accounting occurs and the financial impact that results from convergence. Also, it is instructive to observe the extent of the impact of politicians and private groups on the final standards for fair value accounting. Finally, the determination of compliance costs with fair value accounting is important.

\section{AUTHOR INFORMATION}

Catherine M. Baluch is a Senior Accountant with Gartner, Inc. in Fort Myers. She is currently enrolled in the MBA program at FGCU and pursuing her CPA designation. Originally from Brooklyn, New York, Catherine relocated to Florida in 1998 to attend the University of Miami. She received her BS degree in 2002, with concentrations in Finance and Business Law.

Reuben A. Cohen is a Revenue Agent with the IRS in Fort Myers. He received his BS degree in Hospitality Management from the University of Nevada, Las Vegas. Currently, he is a MS candidate in Accounting at the Florida Gulf Coast University.

Henry Soto is a Senior Accountant with Internal Medicine Associates of Lee County, MD, PA. He received his BS in accounting in 1994 from Manhattan College in New York. He worked at Schmidt, Piscitell and Schwartz, CPA's as a staff accountant (New York, 1994-1997). Before moving to Florida in 2004, he worked at Memorial Sloan Kettering Cancer Center as an Audit and Control Specialist (1997-04).

Pamela J. Tucker is the Business Manager for the Continuing Education division of FGCU. Prior to FGCU, she worked as a Staff Accountant and Paralegal at WCI Communities, Inc. (2002-2008). She received her BS degree in accounting from the International College (2001) and is currently in the Master of Accounting and Taxation program at FGCU. 
Ara G. Volkan, Ph.D., CPA, joined the FGCU faculty in August 2004 as Eminent Scholar and Moorings Park Chair of Managerial Accounting. He received his doctorate in accounting from the University of Alabama in 1979. He holds a CPA certificate in Florida (1989). Following his teaching engagements at Syracuse University (1979-1985) and at University of South Alabama (1986-1989), Dr. Volkan chaired the Accounting and Finance Department at University of West Georgia (1989-2003). Prior to joining the faculty at FGCU, he was Interim Dean at the Richards College of Business at West Georgia (2003-2004). He currently serves as the Associate Dean for Administration and Chair of the Accounting Department.

Gail B. Wright, DBA, CPA, joined the FGCU faculty as Professor of Accounting in August 2007. She received her doctorate in accounting from the George Washington University in 1985. Previously she taught at the University of Richmond (1983-1994) and at Bryant University (1994-1996).

\section{REFERENCES}

1. Allen, F. and Carletti, E. (August 2008). Mark-to-Market Accounting and Liquidity Pricing. Journal of Accounting and Economics, 358-378.

2. Arya, A., and Reinstein, A. (August 2010). Recent developments in fair value accounting. The CPA Journal, 20-29.

3. Bates, H., Calhoun, C., McAllister, J., \& Waldrup, B. (July/August 2009). Don’t Shoot the Messenger: The Mark-to Market Issue. Florida CPA Today, 16-17.

4. Boyles, J. (August 2008). Fair Value Accounting: Are You Ready. Strategic Finance, 29-32.

5. Campbell, R., Owens-Jackson, L., and Robinson, D. (July 2008). Fair Value Accounting: From Theory to Practice. Strategic Finance, 31-37.

6. Cheng, Kang. (August 2009). Fair Value's 'How' Meets 'When'. The CPA Journal, 26-29.

7. Donatio, P. (Spring 2009). The Quest for Greater Transparency in Valuation and Pricing. J.P.Morgan Online, 1-3.

8. Duangploy, O., and Pence, D. K. (March 2010). Practical Implications of Fair Value Hedges and AFS Debt Securities. The CPA Journal, 28-35.

9. Dzinkowski, R. (January 2009). Mark to Market: Does This Accounting Rule Fix Problems or Create Them? Strategic Finance, 33-37.

10. Epstein, B. (September 2009). Two Threats to Sound Accounting by Banks and Thrifts. The CPA Journal, 20-24.

11. Epstein, B., Nach, R., and Bragg, S. (2009). Interpretation and Application of Generally Accepted Accounting Principles. New Jersey: John Wiley \& Sons, Inc.

12. Financial Accounting Standards Board. (2009). Accounting Standards Codification Sections 820 and 825.

13. Foster, B., and Shastri, T. (April 2010). The Subprime Lending Crisis and Reliable Reporting. The CPA Journal, 20-25.

14. Fuglister, J, and Bloom, R. (January 2008). Analysis of SFAS 157, Fair Value Measurements. The CPA Journal, 36-39.

15. Gross, J. (March 2009). The Tail Wagging the Dog. Mortgage Banking, 70-75.

16. Holmes, F. (Spring 2009). FAS 157 and Other Regulatory Actions: Good Intentions, Unintended Consequences. Seeking Alpha, 1-4.

17. Katz, D. (September 2008). Fair-Value Revolution. CFO, 50-56.

18. King, A. (January 2009). Determining Fair Value. Strategic Finance, 27-32.

19. Krumwiede, T., Scadding, R., and Stevens, C. (May 2008). Mortgage-Backed Securities and Fair-Value Accounting. The CPA Journal, 30-36.

20. Levitt, A., and Breeden, R. (June 2009). The CPA Journal, 6-12.

21. Ma, C., and MacNamara, A. (January 2009). When Fair Value is not Fair. The CPA Journal, 10-11.

22. McDonald, L. (January 2010). Fair Value Changes Ahead. The CPA Journal, 24-27.

23. Miller, W. (August 2008). The Fatal Flaw in SFAS No. 157. Strategic Finance, 41-47.

24. Mosso, D. (March 2010). Transparency Unveiled: Financial Crisis Prevention through Accounting Reform. Accounting Horizons, 95-107.

25. Norris, F. (September 11, 2009). Accountants Misled Us Into Crisis. The New York Times, B1. 
26. Plantin, G., Sapra, H., and Shin, H. S. (May 2008). Marking-to-Market: Panacea or Pandora's Box? Journal of Accounting Research, 435-460.

27. Ryan, S. (November 2008). Accounting in and for the Subprime Crisis. The Accounting Review, 16051638.

28. Trott, E. (December 2009). Accounting for Debt Instruments Held as Assets. Accounting Horizons, 457469.

29. Trussel, J., and Rose, L. (June 2009). Fair Value Accounting and the Current Financial Crisis. The CPA Journal, 26-30.

30. Zabel, R., and Morrell, A. R. (2009 January). SFAS 157: What Is Its Purpose? Robins, Kaplan,

31. Miller, and Ciresi L.L.PNewsletter, 1-4. 
NOTES 